\title{
Public Restrooms: Flipping the Default Rules
}

\author{
RUTH COLKER*
}

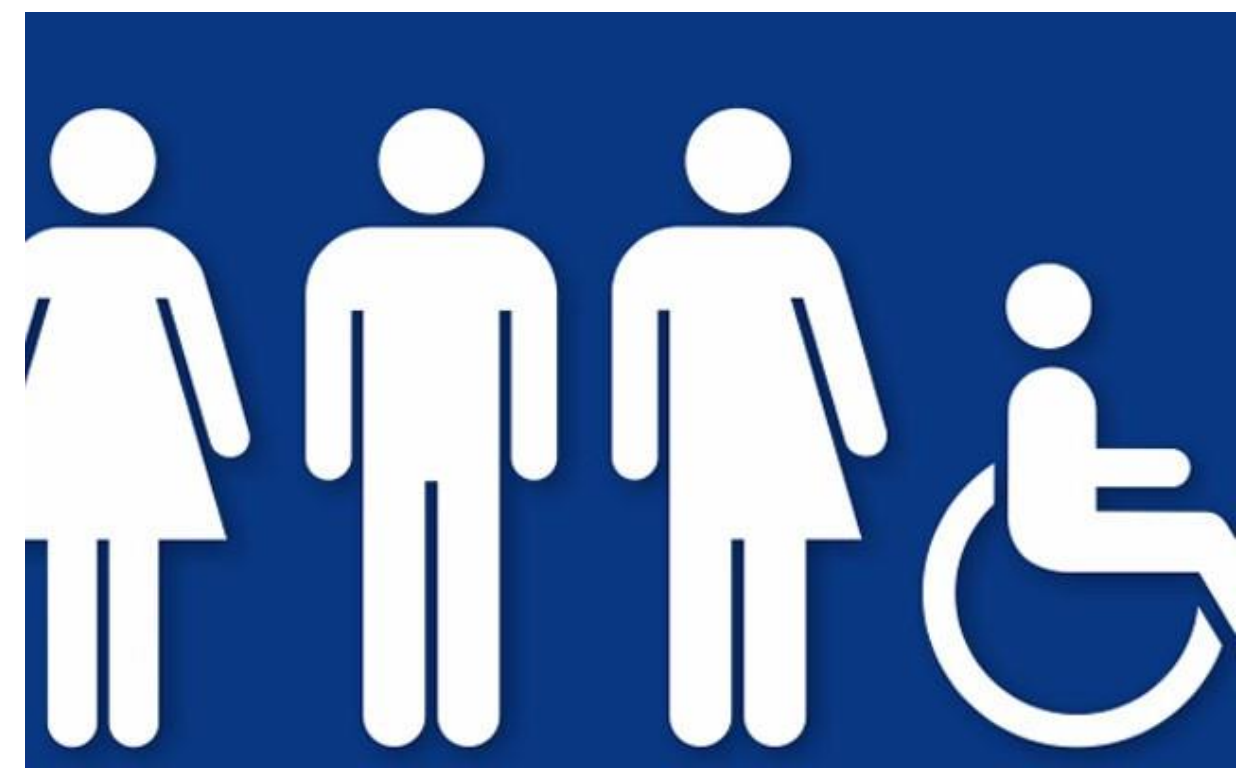

TABLE OF CONTENTS

I. INTRODUCTION 146

II. THE EMERGENCE AND ENTRENCHMENT OF SEX-SEGREGATED RESTROOMS

A. The History of the Public Restroom ....................................152

B. The Fear of "Unisex" Bathrooms .........................................157

III. Public Restrooms AS A Constitutional Violation ...............160

A. State Action ......................................................................... 160

B. The Harm Created by Sex-Segregated Restrooms ..................161

1. Introduction ................................................................... 161

2. Sex-Segregated Bathrooms as Sexual Stereotyping........163

3. Women's Exclusion from All-Male Space........................167

C. Some Doctrinal Complications ..........................................169

* Ruth Colker, Distinguished University Professor \& Heck-Faust Memorial Chair in Constitutional Law, Moritz College of Law, The Ohio State University. I would like to thank Moritz librarian Stephanie Ziegler for her assistance and Professors Martha Chamallas, Carla Corroto, David Levine, Marc Spindelman, and Timothy Zick, as well as the students in my Sex, Sexuality and the Law class, for their helpful suggestions. The image can be found at The Young Turks, New Law Requires Gender Neutral Bathroom Signs, YouTuBE (Jan. 17, 2015), https://www.youtube.com/watch?v=OftnXxA_t-I [https://perma.cc/9ZMM-9WKD]. It is reportedly being displayed in West Hollywood, California where local law requires all single-stall restrooms to be gender neutral. 
D. Justifications for Sex Segregation ...................................171

1. Privacy ............................................................... 171

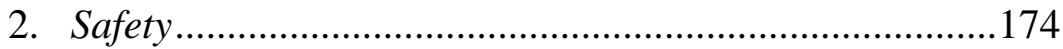

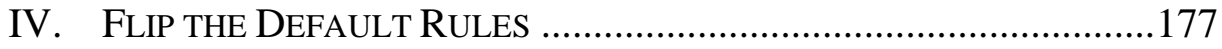

\section{INTRODUCTION}

Public $^{1}$ restrooms $^{2}$ are the historical site for many civil rights struggles. "Whites only" signs are a reminder of the commonplace racial segregation found in the southern United States prior to $1964 .{ }^{3}$ In the southwest United States, restroom signs in the 1950s often read "Mexicans and Dogs not allowed." 4 Not only did racially-segregated restrooms send a message of inferiority to racial minorities, ${ }^{5}$ they also limited their ability to travel across

${ }^{1}$ The term "public" refers to any restroom outside the home; it could be a restroom maintained by a public entity, such as a city, as well as a restroom maintained by a private entity, such as a restaurant or hotel. As discussed in Part II, infra, the original "public" restrooms were those financed by local government in public spaces. Over time, the word has come to encompass restrooms found in private, commercial establishments.

2 The term "rest room" or "restroom" developed in the early twentieth century to describe public washrooms in small towns "which aimed to serve farm families in town for a day of shopping. Located in business blocks or homes near the business district, the small-town 'rest rooms' were like domestic spaces with small toilet rooms and larger parlors, dining rooms and kitchens." Peter C. Baldwin, Public Privacy: Restrooms in American Cities, 1869-1932, 48 J. SOC. HIST. 264, 274 (2014). Other terms that are sometimes used to convey similar meaning are bathroom, toilet facility, and potty. ERA opponents coined the term "unisex bathrooms" to describe sex-integrated bathrooms. See infra Part II.B.

${ }^{3}$ C.J. Griffin, Workplace Restroom Policies in Light of New Jersey's Gender Identity Protection, Note, 61 RuTGERS L. REV. 409, 423-24 (2009) (documenting race-segregated facilities under Jim Crow); see also Baldwin, supra note 2, at 277 ("Southern cities did segregate the races. Dallas, for instance, built an underground restroom in 1915 with separate sections for whites and blacks. Atlanta opened one in 1921 with a room for white women on the second floor, white men on the first floor, and blacks in the basement."). In 1964, Congress banned such racial segregation through the enactment of Title II of the Civil Rights Act of 1964, Pub. L. No. 88-352, § 201(a), 78 Stat. 241, 243 (codified at 42 U.S.C. § 2000a(a) (2012)).

${ }^{4}$ Lilian Jiménez, America's Legacy of Xenophobia: The Curious Origins of Arizona Senate Bill 1070, 48 CAL. W. L. REV. 279, 289 (2012) ("Mexicanos were segregated in schools, railroads, hotels restaurants, public bathrooms, and other public accommodations. Signs in public places commonly read 'Mexicans and Dogs not allowed.' Historians have documented how a large number of Mexicanos were robbed of their land and subjected to a dual wage system, segregation, and lynching." (footnotes omitted) (quoting Karla Mari McKanders, Identification of Race in the Law: Sustaining Tiered Personhood: Jim Crow and Anti-Immigrant Laws, 26 HARV. J. ON RACIAL \& ETHNIC JusT. 163, 182 (2010))).

${ }^{5}$ For a graphic description of racially segregated bathrooms and drinking fountains, see Elizabeth Abel, Bathroom Doors and Drinking Fountains: Jim Crow's Racial Symbolic, 25 CRITICAL INQUIRY 435, 452 (1999). 
the United States, including many areas in the North, ${ }^{6}$ because the "whites only" restroom would often be the only convenient restroom. ${ }^{7}$

The disability rights community has also fought for restroom access. When Congress enacted the Americans with Disabilities Act (ADA) in 1990, ${ }^{8}$ restroom accessibility was given a very high priority ${ }^{9}$ because it is impractical to travel outside the home if one does not have access to restrooms. Inaccessible restrooms were the "[a]ble-bodied only" sign for the disability community. ${ }^{10}$ As with whites-only restrooms, the inaccessible restroom might be the only convenient restroom. ${ }^{11}$

A less-recognized accessibility problem when the ADA was enacted in 1990 was the inaccessibility of restrooms for those individuals who used opposite-sex ${ }^{12}$ companions to assist with toileting. Even if a restroom met ADA accessibility guidelines, it might be unavailable for a person with a disability, who used assistance, if that restroom were limited to people of one

${ }^{6}$ Paul Finkelman, The Radicalism of Brown, 66 U. PITT. L. REV. 35, 41 (2004) ("Blacks reported that despite laws which prohibited discrimination it was 'difficult to find a meal or a hotel room in the downtown areas of most northern cities.' Enforcement of such laws was lax and businesses 'discouraged [blacks] from patronizing places by letting them wait indefinitely for service, charging them higher prices, giving poor service, and publicly embarrassing them in various ways.' Although illegal, 'whites only' signs could be found in some places in the North. But, generally such signs were unnecessary, as some businesses simply refused to accommodate or serve blacks." (alteration in original) (footnotes omitted) (quoting President's Comm. ON CIVIL Rights, To SECure These Rights: THE REPORT OF THE PRESIDENT'S COMMITTEE ON CiVIL Rights 78 (1947))).

7 Jennifer Levi \& Daniel Redman, The Cross-Dressing Case for Bathroom Equality, 34 SeAttle U. L. REV. 133, 139 (2010) ("[Often] in the workplace, blacks had to travel great distances to use the restroom, while white restrooms were generally just off the shop floor." (alteration in original) (quoting Griffin, supra note 3, at 424)).

8 Americans with Disabilities Act of 1990 (ADA), Pub. L. No. 101-336, 104 Stat. 327 (codified as amended in scattered sections of 42 U.S.C.).

${ }^{9}$ Id. $\$ 227$ (codified at 42 U.S.C. $§ 12147(\mathrm{a})$ ).

${ }^{10}$ Americans with Disabilities Act of 1989: Hearings on S. 933 Before the Comm. on Labor \& Human Res. \& the Subcomm. on the Handicapped, 101st Cong. 78 (1989) (statement of Neil Hartigan, Att'y Gen. of Illinois) ("All of us can surely agree that the time is long since past when it was legal or morally acceptable for public facilities to have signs saying, 'Whites only'. But a restaurant or a theater with steps for an entrance, or an office building with a third floor bathroom and no elevator in effect has a sign saying 'Able-bodied only'.').

${ }^{11}$ See, e.g., Berthiaume v. Doremus, 998 F. Supp. 2d 465, 474 (W.D. Va. 2014) (holding in favor of a restaurant patron who used a walker and sued a restaurant for lack of an accessible entrance and restroom).

12 This Article uses the terms "sex" and "gender" interchangeably, typically relying on the way the term is used by those making a particular argument. By using the term "opposite-sex," I do not mean to endorse the concept that the sexes are "opposites," but this is how this issue has historically been considered as part of the disability rights discourse. 
sex. ${ }^{13}$ Public accommodations sometimes have addressed this problem by offering family-style restrooms that are not limited to people of a single sex. ${ }^{14}$

Nonetheless, the creation of family-style restrooms as a solution to the opposite-sex companion problem for the disability community segregates individuals with disabilities from others; the disability rights community typically opposes segregation. ${ }^{15}$ The exclusion of people with disabilities from some public, inaccessible restrooms may heighten nondisabled people's sense of people with disabilities as "other" while also limiting social access between people who are disabled and nondisabled people.

The disability rights community also supports the right of a person with a disability to bring an opposite-sex companion into a single-sex restroom; ${ }^{16}$ covered entities must comply with this request under the ADA. ${ }^{17}$ Because the disability rights community supports this right, it has opposed North Carolina's House Bill 2,18 which limits that kind of assistance. ${ }^{19}$ By contrast, California has a rule requiring safety roadside rest areas to permit a person with a disability to be accompanied in a communal, sex-segregated restroom

${ }^{13}$ For a testimonial of that problem, see Shelley Peterman Schwarz, In Search of a Unisex Restroom, INSIDE MS, Jan.-Mar. 2003, at 67, 67-68, describing how she was able to sit on the toilet but was unable to get back up because her male assistant could not be in the female restroom.

14 See Kathryn H. Anthony \& Meghan Dufresne, Potty Parity in Perspective: Gender and Family Issues in Planning and Designing Public Restrooms, 21 J. PlAN. LiTERATURE 267, 283 (2007) (discussing the availability of family-style restrooms); Unisex \& Family Restrooms, AM. RESTROOM ASS'N, http://www.americanrestroom.org/family/ [https://perm a.cc/55PF-C9M6] (describing advantages of a family-style restroom for people with disabilities).

${ }^{15}$ See generally Olmstead v. L.C. ex rel. Zimring, 527 U.S. 581 (1999) (holding that the ADA contains an integration principle). "The preamble to the Attorney General's Title II regulations defines 'the most integrated setting appropriate to the needs of qualified individuals with disabilities' to mean 'a setting that enables individuals with disabilities to interact with non-disabled persons to the fullest extent possible."' $I d$. at 592 (quoting 28 C.F.R. pt. 35 app. A, at 450 (1998)).

16 Disability Rights N.C., HB 2 HaRms North CAROLINIANS With Disabilities (Apr. 2016), http://www.disabilityrightsnc.org/sites/default/files/HB2\%20response\%20DR NC.pdf [https://perma.cc/3V2S-BT8K].

17 See Civil Rights Div., U.S. DeP'T of Justice, ADA Best Practices ToOK Kit FOR STATE AND LOCAL GOVERNMENTS ch. 1, at 8-9 (Dec. 2006), https://www.ada.gov/pcat oolkit/chap1 toolkit.pdf [https://perma.cc/ND48-C74Q] (providing this as an example of a reasonable modification under 28 C.F.R. $\$ 35.130(b)(7))$.

${ }^{18}$ Public Facilities Privacy \& Security Act, H.B. 2, 2016 Gen. Assemb., 2d Extra Sess. (N.C. 2016).

${ }^{19}$ See, e.g., DisABILITY RightS N.C., supra note 16 ("There is no exception that allows a person with a disability to enter a restroom in a public agency that is assigned to the sex of his or her caregiver. Example: A twelve year old boy with a disability who needs assistance to use the restroom and whose caregiver is his mother will need to use the men's room at the NC Museum of Natural Sciences, though his mother may enter to provide him assistance."). 
by a person of the opposite sex, and for specific signage to indicate that option. ${ }^{20}$

The specter of "unisex bathrooms" helped derail the ratification of the federal Equal Rights Amendment (ERA) in the 1970s and 1980s. ${ }^{21}$ ERA opponents invoked the symbol of unisex bathrooms to attack sex-integrated bathrooms on the basis that such bathrooms would make society unisex by leading to the end of gender differentiation. ${ }^{22}$ By contrast, feminists have recently sought "potty parity" laws, which redesign restrooms so that women wait no longer than men to use a toilet, nor walk further than men to access restrooms in public spaces. ${ }^{23}$ These "potty parity" laws do not challenge the sex segregation itself.

The debate regarding restroom access has also occurred in the transgender context - whether the Obama Administration had the regulatory authority under Title IX of the Education Amendments of $1972^{24}$ to issue guidance that required educational entities to allow students and faculty to use the communal, sex-designated restroom with which they self-identify and not limit transgender members of the community to restrooms with single stalls. ${ }^{25}$

${ }^{20}$ See CAL. STS. \& HigH. CODE $\S 223.5$ (West 2005). By allowing only people with disabilities to sex-integrate restrooms, one might argue that these kinds of exceptions "desex" individuals with disabilities. The disability rights community has had to argue historically that it, too, should be considered to be "sexual." See, e.g., William Burr, Sexuality of the Disabled Often Overlooked, 183 CMAJ NEWS E259 (Mar. 22, 2011).

${ }^{21}$ See Levi \& Redman, supra note 7, at 139-40; see also Paul A. Freund, The Equal Rights Amendment Is Not the Way, 6 HARV. C.R.-C.L. L. REV. 234, 240 (1971) ("One of the prime targets of the equal-rights movement has been the color-segregated public rest room. Whether segregation by sex would meet the same condemnation is at least a fair question to test the legal assimilation of racism and 'sexism.'"). Although Phyllis Schlafly is often given credit for promoting the specter of "unisex bathrooms," I have not been able to find any primary evidence in support of that statement or her use of that specific term. See, e.g., Juliet Eilperin, New Drive Afoot to Pass Equal Rights Amendment, Wash. Post (Mar. 28, 2007), http://www.washingtonpost.com/wp-dyn/content/article/2007/03/27/AR2 007032702357.html [https://perma.cc/D4LZ-MCJE] (claiming that Schlafly raised fear of unisex restrooms, but offering no support for that statement). Instead, I have found one of her newsletters where she mentions that Professor Freund "demolishes the argument that we could maintain separate rest rooms on the principle of the "right of privacy." Phyllis Schlafly, The Right to be a Woman, PHYLlis Schlafly REP., Nov. 1972.

${ }^{22}$ See infra Part II.B.

23 See Anthony \& Dufresne, supra note 14, at 278-80.

2420 U.S.C. $\$ \S 1681-1686$ (2012).

25 See U.S. DeP'T OF Justice \& U.S. DeP'T OF EduC., DeAr COlleague LeTter on TRANSGENDER STUdENTS 4 (May 2016). This Article is being written following the inauguration of Donald Trump as President of the United States. The Department of Education and Department of Justice in the new Administration has revoked that guidance. See Sandhya Somashekhar et al., Trump Administration Rolls Back Protections for Transgender Students, WASH. PosT (Feb. 22, 2017), https://www.washingtonpost.com/loca 1/education/trump-administration-rolls-back-protections-for-transgender-students/2017/02/ 22/550a83b4-f913-11e6-bf01-d47f8cf9b643_story.html?utm_term=.64dce951ab3d [https:/ 
While that debate is important, the authority of the Obama Administration to issue that guidance is not the subject of this Article.

This Article raises a different question: is it constitutional for public entities to continue to require sex-segregated restrooms? ${ }^{26}$ Transgender individuals are not necessarily the most appropriate people to challenge the sex segregation of restrooms, because they sometimes have an interest in proclaiming their gender self-identification in a sex-segregated restroom as part of their transition process. ${ }^{27}$ They may want to use sex-segregated restrooms as an expression of their gender identity. ${ }^{28}$ People who object to being required to choose a sex-segregated restroom may be more appropriate plaintiffs to challenge the sex segregation of restrooms.

Sex-segregated restrooms constitute a violation of the sexual stereotyping and formal equality principles underlying constitutional law. The commonplace, stick-figure signage reflects blatant sexual stereotyping. ${ }^{29} \mathrm{Few}$ women probably recognize themselves as a stick figure wearing a triangle dress or skirt. ${ }^{30}$ Yet, women often have to accept that symbol as reflecting themselves as they enter public restrooms. ${ }^{31}$ Restrooms signs are symbolic "Barbie" dolls with their exaggerated and reinforcing sense of what it means to

/perma.cc/E6JY-P25R]. The propriety of the Obama Administration guidance, however, is not the subject of this Article.

${ }^{26}$ This issue has not yet been raised in the litigation over sex-segregated bathrooms. In G.G. ex rel. Grimm v. Gloucester County School Board, the plaintiff raised an equal protection claim to argue that he, as a transgender male, was entitled to use the men's restroom even if the Department of Education guidance did not require that result. See G.G. ex rel. Grimm v. Gloucester Cty. Sch. Bd., 132 F. Supp. 3d 736, 738 (E.D. Va. 2015), rev'd in part and vacated in part, 822 F.3d 709 (4th Cir. 2016), vacated and remanded, No. 16-273, 2017 WL 855755 (S. Ct. Mar. 6, 2017) (mem.). But the plaintiff did not challenge the segregation of restrooms themselves under the Constitution. Id. at 745.

27 See, e.g., G.G. ex rel. Grimm v. Gloucester Cty. Sch. Bd., 822 F.3d 709, 716 (4th Cir. 2016) (requesting use of the boys' bathroom as a way to confirm his gender identity), vacated and remanded, No. 16-273, 2017 WL 855755 (S. Ct. Mar. 6, 2017) (mem.).

${ }^{28} I d$.

${ }^{29}$ See Price Waterhouse v. Hopkins, 490 U.S. 228, 251 (1989) (recognizing the sexual stereotyping theory under Title VII of the Civil Rights Act of 1964). For further discussion of the harms perpetuated by sex-segregated restrooms, see infra Part III.B.

${ }^{30}$ Although not all bathroom signage features the same images, my review of stock images suggests that the woman nearly always is wearing a dress or skirt of some sort, and the man is always clothed in long pants. See GoOGLE, https://www.google.com/search?q= male+female+bathroom+sign+images \&biw $=1260 \& b i h=776 \&$ source $=1 n m s \&$ tbm $=i s c h \& s a$ =X\&ved=0ahUKEwiPl-jHmuzPAhXJLSYKHV1OCc4Q_AUIBigB [https://perma.cc/YZZ 9-M8CP] (images resulting from a Google search on Jan. 11, 2017). One exception is a handicapped-accessibility sign, which clearly indicates it is "inclusive." See ADA SIGN DEPOT, https://encryptedtbn2.gstatic.com/images?q=tbn:ANd9GcRZMyAzz0d_cpXBFPa MK3oZA8PIDHaktbCnHpdiqn72Y6mBYoeZ [https://perma.cc/M24S-9Y3N].

${ }^{31}$ See Katherine M. Franke, The Central Mistake of Sex Discrimination Law: The Disaggregation of Sex from Gender, 144 U. PA. L. REV. 1, 57 (1995). 
be "female." 32 Even if the stick-figure, restroom signage were to change, women and men must needlessly sort themselves by gender each time they use a public restroom and comply with the gender-based privacy norms within those spaces. ${ }^{33}$ Those privacy norms also reflect sexual stereotyping. ${ }^{34}$ Further, contemporary public restrooms violate principles of formal equality, as they echo the educational segregation of the past when students lined up by sex each time they entered the school building ${ }^{35}$ and perpetuate a type of allmale private club by excluding women from business, social, and political interactions with men. ${ }^{36}$

Part II of this Article will trace the complicated mixture of moralistic, gendered, racial, and class concerns that underlie the history of the construction of sex-segregated restrooms. These historical roots can explain the placement and design of restrooms in contemporary public spaces. Part III will argue that sex-segregated restrooms constitute an unconstitutional, sex-

${ }^{32}$ Barbie dolls are anatomically impossible. See, e.g., Galia Slayen, The Scary Reality of a Real-Life Barbie Doll, HuFFINGTON POST, http://www.huffingtonpost.com/galiaslayen/the-scary-reality-of-a-re_b_845239.html [https://perma.cc/SR8K-C2G5] (last updated June 8, 2011).

${ }^{33}$ See infra Part III.B.2 (discussing different privacy norms for male and female restrooms).

${ }^{34}$ See infra Part II.

35 While this is a strong memory from my own public school days in the 1960s and 1970s, this practice was apparently not confined to primary schools. See Betty W. Taylor, A History of Race and Gender at the University of Florida Levin College of Law 19092001, 54 FLA. L. REV. 495, 501 (2002) ("Clara Floyd Gehan, in a biography, describes her first day experience at the law school as 'quite stressful as all the students (male) lined up outside the law school building and formed two lines through which she had to traverse in order to enter."' (quoting Clara Gehan, First Lady of the Law School Retires, EIGHTH JuD. CIRC. B. ASS'N NEWSL., Jan. 1989, at 13)). It is also possible that my description of this experience being "in the past" may be inaccurate, although such a practice would be inconsistent with Title IX's rules against sex segregation in public education. Title IX states: "No person in the United States shall, on the basis of sex, be excluded from participation in, be denied the benefits of, or be subjected to discrimination under any education program or activity receiving Federal financial assistance...." 20 U.S.C. $\S 1681(\mathrm{a})$ (2012).

36 See Miriam A. Cherry, Exercising the Right to Public Accommodations: The Debate over Single-Sex Health Clubs, 52 ME. L. REV. 97, 102 (2000). The Clinton-Trump political campaign reminded us of the male conversations that may occur in what are described as "locker rooms" but apparently extend to all-male busses on movie sets. See David A. Fahrenthold, Trump Recorded Having Extremely Lewd Conversation About Women in 2005, WASH. POST (Oct. 8, 2016), https://www.washingtonpost.com/politics/tru mp-recorded-having-extremely-lewd-conversation-about-women-in-2005/2016/10/07/3b9c e776-8cb4-11e6-bf8a-3d26847eeed4_story.html [https://perma.cc/3M54-6RZX] (transcript of the "locker room" conversation). These conversations are apparently affected by the absence of women from these spaces. When Donald Trump left the locker room of the bus, and entered a space with a woman, he changed his demeanor to conform to public norms. See id. That kind of locker room distinction is facilitated by sex segregation. Nonetheless, the sex segregation of locker room spaces is beyond the scope of this Article although it may cause harms similar to those discussed in this Article. 
based harm that cannot be justified under contemporary constitutional, sex discrimination doctrine. While other authors have posited that it is a violation of sex-based equality principles to sex segregate restrooms, ${ }^{37}$ few authors have considered how this claim would be articulated as a constitutionally-based argument. ${ }^{38}$ This Article will argue that the privacy and safety justifications that are offered to defend this practice rely on impermissible sexist and heteronormative understandings of privacy and safety. Part IV will offer a novel remedy for this constitutional harm by suggesting that we should flip the default rules. We should transition towards making large, communal public restrooms available to "all-comers," with a variety of private toileting options, as well as have available a limited number of single-stall restrooms. This solution would allow anyone to pick an entirely private option of a single stall while not forcing everyone to sex identify as a precondition to entering a communal restroom. The stick-figure signage of sex segregation would become an historical relic.

\section{THE EMERGENCE AND ENTRENCHMENT OF SEX-SEGREGATED RESTROOMS}

\section{A. The History of the Public Restroom}

Today, we think of restrooms in retail stores and restaurants as "public" restrooms because they are outside the home. ${ }^{39}$ But, historically, "public" restrooms referred only to restrooms created in noncommercial, public spaces $^{40}$ for the use of people who did not yet have a toilet in their home. ${ }^{41}$ The story of the development of the public restroom encompasses considerations of race, class, moralism, and gender.

When cities installed public urinals in the nineteenth century, the "facilities were intended to stop men from stinking up the streets and exposing

37 See, e.g., Mary Anne Case, Why Not Abolish Laws of Urinary Segregation?, in Toilet: Public Restrooms AND THE Politics OF Sharing 211, 215-16 (Harvey Molotch \& Laura Noren eds., 2010). It is also possible that bathroom rules constitute a violation of freedom of speech or freedom of association principles. See generally Timothy Zick, Bathroom Bills, the Free Speech Clause, and Transgender Equality, 78 OHIO ST. L.J. (forthcoming 2017). That argument goes beyond the scope of this Article.

${ }^{38}$ See, e.g., Kelly Levy, Note, Equal, But Still Separate?: The Constitutional Debate of Sex-Segregated Public Restrooms in the Twenty-First Century, 32 WomEN's RTS. L. REP. 248, 251-52 (2011); Alex More, Note, Coming Out of the Water Closet: The Case Against Sex Segregated Bathrooms, 17 TEX. J. WoMEN \& L. 297, 305-15 (2008).

${ }^{39}$ Thus, the transgender fight for the use of restrooms often challenges the rules at work or commercial establishments rather than facilities created by local government for the use of its citizens. See, e.g., Etsitty v. Utah Transit Auth., 502 F.3d 1215, 1219 (10th Cir. 2007) (concerning a transgender, female bus driver who was fired because she insisted on using women's restrooms while driving her bus route).

${ }^{40}$ Baldwin, supra note 2, at 270.

${ }^{41} \mathrm{Id}$. at 266-67. 
their genitals while urinating against convenient walls. Many nineteenthcentury facilities did not accommodate women, who were not known for such indiscreet behavior." 42 The construction of public restrooms was initially an urban phenomenon in response to the "stench of feces and rotting garbage," especially in densely populated areas. ${ }^{43}$

One of the earliest public restrooms was built in Astor Place in New York City in $1869 .{ }^{44}$ It included a men's restroom with "three stalls for urination and two seats, but without stall doors for privacy." 45 The women's restroom, which ended up being comparatively underutilized, included two stalls and a washbasin with little privacy. ${ }^{46}$ It is hard to know if women shunned this public restroom because of the limited privacy or the cramped space, which could have proven challenging for middle-class women who might be wearing crinolines or bustles. ${ }^{47}$

The notion of sex-segregated privacy took some time to evolve. "Poorer people in tenements used communal privies." ${ }^{48}$ Even in middle-class homes, which might contain indoor plumbing, it was common to find two-seat privies with men and women comfortable with relieving themselves in the view of others. 49 "Urinating men, like defecating horses, were an everyday sight on the street." 50

The sex segregation of public toilets emerged consistently with the development of nineteenth-century middle-class moralism. ${ }^{51}$ "The nineteenthcentury, urban middle class increasingly viewed all forms of bodily restraint as essential to respectability." 52 It was important to conceal "organic processes" like nose-blowing, coughing, scratching, urinating, and defecating. ${ }^{53}$ It was also thought that women were the weaker sex and needed sex-segregated facilities at work, for example, because they might have "sudden attacks of

${ }^{42} I d$. at 266.

${ }^{43} I d$. at $266-67$.

${ }^{44} I d$. at 268 .

${ }^{45} \mathrm{Id}$.

46 Baldwin, supra note 2, at 268-69.

${ }^{47} I d$. at 269.

${ }^{48} I d$. at 266.

${ }^{49} \mathrm{Id}$. at 267.

${ }^{50} I d$.

${ }^{51}$ Sheila Jeffreys, The Politics of the Toilet: A Feminist Response to the Campaign to 'Degender' A Women's Space, 45 WoMEN's STUD. INT'L F. 42, 42 (2014) (stating that feminists often argue that "the idea of segregating women's toilets is reactionary and was the result of nineteenth century moralism"); see also TRANSGENDER LAW CTR., PEEING IN PEACE: A Resource GuIDE FOR TRANSGENDER ACTIVISTS AND Allies 3 (2005) (“Over 150 years ago, only wealthy people could afford bathrooms in their homes and poor people were forced to use insufficient, non-hygienic public toilets.”).

${ }_{53}^{52}$ Baldwin, supra note 2, at 267.

${ }^{53} \mathrm{Id}$. 
dizziness, fainting or other symptoms of illness, for whose use provision should be made in the form of rest or emergency rooms." 54

The sex segregation of restrooms also reflected a heightened interest in segregating middle-class men and women, generally, in public life. Hotels often offered separate entrances for men and women. 55 "Women's entrances to hotels led to more secluded parlors, often one floor up, with comfortable seating, carpets and drapes." 56 And a hotel's washroom might be for "public use" because other restrooms were available in the private suites on the upper floors. ${ }^{57}$ The "public" would be limited to "[w]ell-dressed people [who] used hotel lobbies and parlors as places to meet, loiter and people-watch, even if they were not checked in as guests." 58 Similarly, department stores increasingly offered opulent restrooms to their female customers but classsegregated their clientele by offering " 'bargain basements' to serve poorer people" who would not be likely to enter the upper floors that contained the high quality restroom facilities. ${ }^{59}$ The department stores made the restrooms available because they understood that women would not be likely to frequent their businesses unless they had a place to use a toilet. ${ }^{60}$

In spaces where the social classes and ethnic groups might mix, like railroad stations, there was special attention to sex and ethnic segregation. ${ }^{61}$ Foreign immigrants might be assigned their own second-class facilities with "waiting rooms complete with dining, restroom and laundry facilities." 62 Not only were women offered their own restroom space but also there was special attention paid to enhancing the privacy of these spaces so that "[n]o one looking into the women's waiting room should be able to glimpse that sacred portal." 63

Civic groups began to push for more sanitary public toilets in the early twentieth century as people came to argue that public filth " demoralized' the poor" and "discouraged immigrants' assimilation into American culture."64 Health and morality became connected in the public mind with increased legal attention on the need to protect the physical well-being of women by limiting their working hours, fighting prostitution, and preventing teenage

${ }^{54}$ Terry S. Kogan, Sex-Separation in Public Restrooms: Law, Architecture, and Gender, 14 Mich. J. GENDER \& L. 1, 43 (2007) (quoting GEORGE M. PRICE, JoINT BD. OF Sanitary Control in the Dress \& Waist Indus., SpeCial Report on SANitary CONDITIONS IN THE SHOPS OF THE DRESS AND WAIST INDUSTRY 13 (May 1913)).

${ }_{55}$ Baldwin, supra note 2, at 270.

${ }^{56} \mathrm{Id}$. at 271.

${ }^{57} \mathrm{Id}$.

58 Id. at 270.

${ }^{59} \mathrm{Id}$. at 272.

${ }^{60} \mathrm{Id}$.

${ }^{61}$ Baldwin, supra note 2, at 271 .

${ }^{62} I d$.

${ }^{63} \mathrm{Id}$. at 272.

${ }^{64} I d$. at 273. 
promiscuity. ${ }^{65}$ Writing in 1908, the United States Supreme Court invoked separate spheres ideology to uphold limitations on women's working hours in consideration of women's putative frailty, the need to preserve the "well-being of the race" and "to protect her from the greed as well as the passion of man." 66 The reference to the "well-being of the race" was meant to refer to the white race. ${ }^{67}$ The moral tone of this justification is unmistakable-save her from the greed and passion of men. It is not surprising that public restrooms, constructed around the same time, would be quite attentive to shielding middle-class women from public view.

Further evidence of the influence of notions of morality on restroom construction is the connection between those restrooms and the alcoholprohibition movement. Before noncommercial, public restrooms existed, the "saloon" was often the only place to find a restroom (and it would have been off limits to women). ${ }^{68}$ Some were concerned that men found it difficult to abstain from alcohol if they had to enter a saloon to urinate. ${ }^{69}$ Prohibition advocates argued that "[r]eformers could undermine the saloon's power . . by developing alternatives like coffee shops, singing clubs, and of course comfort stations." 70 When the Eighteenth Amendment was ratified and Prohibition began in 1919, there was increased pressure to build noncommercial, public restrooms so that working-class men would not flock to hotels and stores to use a restroom. ${ }^{71}$

Even as noncommercial, public restrooms became more common in the early twentieth century, women often avoided them. ${ }^{72}$ Middle-class women, who could find restrooms at private department stores or hotels, may have avoided the noncommercial, public restrooms out of a sense of discomfort, invasion of privacy, avoidance of the poor, or concern for safety. ${ }^{73}$ With

\footnotetext{
65 Id. at 274.

${ }^{66}$ Muller v. Oregon, 208 U.S. 412, 422 (1908).

${ }^{67}$ See Cheryl I. Harris, Finding Sojourner's Truth: Race, Gender, and the Institution of Property, 18 CARdozo L. REV. 309, 341 (1996) (discussing how the cult of true womanhood was used to protect white women).

${ }^{68}$ See Baldwin, supra note 2, at 270 ("Saloons provided the only public toilets in industrial areas, waterfronts and residential neighborhoods, a service that saloonkeepers considered as effective as free lunches in attracting customers."); Maureen Flanagan, Private Needs, Public Space: Public Toilets Provision in the Anglo-Atlantic Patriarchal City: London, Dublin, Toronto and Chicago, 41 URB. Hist. 265, 270 (2014) ("Men had traditionally availed themselves of such private spaces as pubs, saloons and men's clubs.").

${ }^{69}$ Baldwin, supra note 2, at 275 (justifying construction of public restrooms in Chicago so that men would not otherwise have "to go into a saloon for the convenience" (quoting Jennie Franklin Purvin, Bathing Beaches \& Pub. Comfort Stations Comm., Movie of a Member of the Committee on Public Comfort Stations, Woman's CiTy Club Bull., Aug. 1918, at 4, 5)).

${ }^{70} \mathrm{Id}$.
${ }^{71} \mathrm{Id}$. at $276-77$.
${ }^{72} \mathrm{Id}$. at 279.
${ }^{73} \mathrm{Id}$. at $278-79$.
} 
women not often using the noncommercial, public restrooms, advocacy for the development of such spaces often diminished. ${ }^{74}$

Nonetheless, some women fought against the limited availability of commercial and noncommercial public restrooms for women as part of an effort to improve women's opportunities in the public spheres of work and shopping. ${ }^{75}$ While the design and construction of these restrooms may have reflected nineteenth-century moralistic views, the very existence of these restrooms may also have been a part of women's attempt to gain greater equality. ${ }^{76}$ Two telling examples of long-standing gender inequality in the legal and political spheres were the absence of a women's restroom in the chambers of the United States Supreme Court until $1981^{77}$ and on the floor of the United States Senate until 1992. ${ }^{78}$ As African-Americans could not readily travel in the southern United States before the enactment of Title II of the Civil Rights Act of $1964^{79}$ due to a lack of availability of public toilets, and individuals with disabilities found themselves unable to readily travel before the enactment of the ADA in $1990^{80}$ due to a lack of accessible toilet facilities, women in the early twentieth century found themselves unable to "access work, education or public space on terms of equality whilst there are no women's toilets." 81

Because of the enduring reality of men having more access to public toilets than women, there has been an increased focus in recent years on "potty parity" laws that would ensure that women have access to adequate toilet facilities. ${ }^{82}$ This argument about the lack of toilets for women is different than the argument about whether and why toilets were sex segregated. Sex segregation was historically based on a combination of concerns about

${ }^{74}$ Id. at 280 .

75 Jeffreys, supra note 51, at 46-47.

76 Id. at 46.

77 See 'Out of Order' at the Court: O'Connor on Being the First Female Justice, NPR (Mar. 5, 2013), http://www.npr.org/2013/03/05/172982275/out-of-order-at-the-courtoconnor-on-being-the-first-female-justice [https://perma.cc/V2Q7-S4DF] (discussing an interview with Justice O'Connor). Justice Ginsburg talks about the "potty problem" as being a rationale for excluding women from law school and the legal profession. See RUTH BADER GinsBURG, My Own WORDS 72, 75 (2016).

78 Irus Braverman, Loo Law: The Public Washroom as a Hyper-Regulated Place, 20 HASTINGS WOMEN's L.J. 45, 60 (2009).

${ }^{79}$ Civil Rights Act of 1964, Pub. L. No. 88-352, tit. II, § 201(a), 78 Stat. 241, 243 (codified at 42 U.S.C. § 2000a(a) (2012)).

${ }^{80}$ See, e.g., 28 C.F.R. $\$ 36.304$ (c)(3) (2016) ("[A] public accommodation should take measures to provide access to restroom facilities.").

81 Jeffreys, supra note 51, at 47 . A lack of access to private or public toilets continues to be a dangerous facet of the lives of many poor girls and women around the world. See Barbara Frost et al., Two Girls Died Looking for a Toilet. This Should Make Us Angry, Not Embarrassed, GUARDIAN (May 31, 2014), https://www.theguardian.com/global-developme $\mathrm{nt} / 2014 /$ jun/01/girls-toilet-rape-murder-anger-embarrassment [https://perma.cc/L4YT4DCS].

${ }^{82}$ See Anthony \& Dufresne, supra note 14, at 277-80. 
privacy, class divisions, and "separate spheres ideology." 83 The impetus to have publicly available restrooms for women, at all, however, may be seen as part of a political movement towards gender-based equality. ${ }^{84}$

In the second half of the twentieth century, noncommercial, public restrooms became much less common and people came to think of "the use of the toilet... to be the result of an agreement between an individual and a business." 85 But the sex-segregated privacy and class sensibilities that were part of the development of the public restroom remain. The "bargain basement" 86 is still on the ground level of a department store with the more upscale offerings often situated near an expensive restaurant with an elegant women's restroom. The more expensive commercial establishments seem to have the most privacy protection within the restroom facility for women. ${ }^{87}$ Thus, notions of women's frailty and enhanced need for privacy may still survive in our conception of sex-segregated restrooms.

\section{B. The Fear of "Unisex" Bathrooms}

Despite the decline in availability of noncommercial, public restrooms in the mid-twentieth century and the absence of any suggestion that public restrooms would become sex integrated, the sex segregation of public restrooms took front and center stage as an argument to derail the proposed federal ERA in the 1970s and 1980s. ${ }^{88}$ When the ERA was being considered, three of the most common objections were that women would be subject to the draft and allowed to enter combat, same-sex marriage would become permissible, and public restrooms would become "unisex."89 Although those arguments helped defeat the federal ERA in 1982, "three states shy of

\footnotetext{
${ }^{83}$ Kogan, supra note 54, at 40-50 (discussing justifications for separate-sex toilet facilities).

84 There has also been increased pressure for men's restrooms to have changing tables so that men, like women, can travel with infants and change their diapers. Congress recently enacted the "Babies Act" to mandate the creation of changing tables in all federal restrooms. Bathrooms Accessible in Every Situation Act, Pub. L. No. 114-235, 130 Stat. 964 (2016) (to be codified as amended at 40 U.S.C. $\$ \S 3314-3317$ ).

85 Baldwin, supra note 2, at 281.

${ }^{86}$ See supra note 59 and accompanying text.

${ }^{87}$ From personal experience using women's restrooms, I have often found elaborate sitting rooms as part of a restroom at an upscale restaurant. My male partner reports no such expansive and private sitting room in the men's restroom.

${ }^{88}$ Franke, supra note 31 , at 75 .

${ }^{89}$ See Barbara A. Brown et al., The Equal Rights Amendment: A Constitutional Basis for Equal Rights for Women, 80 YALE L.J. 871, 901, 976-77 (1971) (responding to the military and bathroom arguments against ERA); Eilperin, supra note 21. Opposition to sexintegrated bathrooms is not just an historical issue. Fear of gender-neutral bathrooms continues today and has been invoked to defeat a Houston nondiscrimination ordinance. See Jeannie Suk Gersen, Who's Afraid of Gender-Neutral Bathrooms?, NEW YORKER (Jan. 25, 2016), http://www.newyorker.com/news/news-desk/whos-afraid-of-same-sex-bathrooms [https://perma.cc/L7YN-4M4T].
} 
ratification," 90 two of those outcomes have largely come to pass through constitutional litigation and political activism. ${ }^{91}$ While we have made significant political and legal advances with respect to the combat and marriage issues, the fear of "unisex bathrooms" has not dissipated.

ERA opponents exploited the specter of "unisex bathrooms" as part of their opposition to the ERA, invoking the fear that gender differences would disappear if men and women used the same communal restrooms. ${ }^{92}$ It was seemingly important to ERA opponents that men and women reaffirmed their gender identity on a daily basis by using restrooms demarcated by malefemale stick figures. Their use of the term "unisex" did not accurately describe the sex-integrated restrooms, which they seemingly feared, because more than one sex would, in fact, be able to use such sex-integrated restrooms; it arguably reflected their fear that men and women would become "unisex" as sex-mandated segregation dissipated. In other words, ERA opponents may have thought that socially-created structures like sex-segregated public restrooms are important mechanisms to promote distinctions on the basis of sex. The "unisex bathroom" mantra reflected a fear of "unisex people," i.e., people who do not identify with bipolar conceptions of male and female. Ironically, the traditional configuration of public restrooms is unisex because only one sex uses a particular restroom.

Anticipating the "unisex bathroom" argument against the ERA, the leading article explaining the potential impact of the ratification of the ERA stated that ratification of the ERA would not end the sex segregation of public restrooms. ${ }^{93}$ Writing in 1971, this is the logic that Barbara Brown and her coauthors used to contend that sex-segregated bathrooms would survive enforcement of the ERA:

[I]t is clear that one important part of the right of privacy is to be free from official coercion in sexual relations. This would have a bearing upon the operation of some aspects of the Equal Rights Amendment. Thus, under current mores, disrobing in front of the other sex is usually associated with sexual relationships. Hence the right of privacy would justify police practices by which a search involving the removal of clothing could be performed only by a police officer of the same sex as the person searched. Similarly the right of privacy would permit the separation of the sexes in public rest rooms, segregation by sex in sleeping quarters of prisons or similar public

${ }^{90}$ Levi \& Redman, supra note 7, at 139.

${ }^{91}$ See Obergefell v. Hodges, 135 S. Ct. 2584 (2015) (marriage equality); Matthew Rosenberg \& Dave Philipps, All Combat Roles Now Open to Women, Defense Secretary Says, N.Y. TIMES (Dec. 3, 2015), https://www.nytimes.com/2015/12/04/us/politics/combatmilitary-women-ash-carter.html?_r=0 [https://perma.cc/6BHM-HCAC] (end of combat exclusion).

92 See Levi \& Redman, supra note 7, at 139-40; see also Franke, supra note 31, at 75 ("Between 1970 and $1980 \ldots$ the second wave of feminism was at its apex and the threat of unisex bathrooms was successfully used to defeat the ERA . ...”).

93 Brown et al., supra note 89 , at 901 . 
institutions, and appropriate segregation of living conditions in the armed forces. ${ }^{94}$

Notice how they justified the continuation of single-sex restrooms after the adoption of the ERA. After adoption of the ERA, one would continue to have the right to (1) be free of sexual coercion and (2) not to disrobe in front of someone who would be considered a possible (hetero)sexual partner. ${ }^{95}$ Even though women's restrooms universally have private stalls that preclude anyone (male or female) from being able to see a woman "disrobing,"96 this superficial argument was used to explain why sex-segregated bathrooms would still be constitutional after the adoption of the ERA. These were not fringe scholars making this argument in an obscure journal; they were preeminent constitutional law scholars making this argument in the pages of the Yale Law Journal to assist the ratification of the ERA by explaining its (limited) consequences. ${ }^{97}$ These scholars proclaimed that the public need not worry about women serving in combat, same-sex marriage, or sex-integrated restrooms if the ERA were adopted. ${ }^{98}$

When the ERA was being considered, some states were so concerned about the "unisex bathroom" problem that they added bathroom exceptions to their nondiscrimination laws. ${ }^{99}$ These preemptive moves were similar to the many states that enacted "mini-DOMAs" out of concern that same-sex marriage would become possible in some states. ${ }^{100}$ These mini-DOMAs were ruled unconstitutional when the Supreme Court ruled in favor of marriage equality, ${ }^{101}$ but these state efforts reflected the deep-seated prejudice against marriage equality. If the federal courts were to rule that state-mandated, sex segregation in restrooms is unconstitutional, then these special bathroom exceptions would have to be struck down as well.

Another way to understand the 1971 article on the ERA is that it reflected recognition that the country was not yet ready for women in combat, same-sex marriage or sex-integrated restrooms. But, as we have seen in the transformation towards women serving in combat ${ }^{102}$ and the availability of

${ }^{94} I d$. (footnote omitted).

${ }^{95} \mathrm{Id}$.

96 Id.

97 Id.

${ }^{98} I d$.

${ }^{99}$ Levi \& Redman, supra note 7, at 140.

${ }^{100}$ See generally Andrew Koppelman, The Difference the Mini-DOMAs Make, 38 LOY. U. CHI. L.J. 265, 265-66 (2007). ("[Such laws] contain the interstate effect of one state's recognition of same-sex marriage.").

101 See Obergefell v. Hodges, 135 S. Ct. 2584 (2015).

102 See, e.g., Martha McSally, Women in Combat: Is the Current Policy Obsolete?, 14 DukE J. GENDER L. \& POL'Y 1011, 1013 (2007); Valorie K. Vojdik, Beyond Stereotyping in Equal Protection Doctrine: Reframing the Exclusion of Women from Combat, 57 ALA. L. REV. 303, 305-06 (2005). 
same-sex marriage, ${ }^{103}$ those changes were possible and were also crucial to the advancement of sex-based equality. The current sex-based configuration of restrooms is not inevitable; changing that well-accepted configuration is essential to dismantling the sexual stereotyping that underlies gender-based inequality.

The need to challenge sex-segregated restrooms is analogous to the need to dismantle Jim Crow by challenging the wholesale segregation by race. When Homer Plessy brought his original challenge to Louisiana's law that required racial segregation of railways, ${ }^{104}$ he was not necessarily seeking to dismantle Jim Crow. He argued his "mixture of colored blood was not discernible" so that he should be able to board the coach reserved for whites. ${ }^{105}$ His argument is parallel to the transgender, male student who requests to use the restroom that is consistent with his self-identity as a man. Homer Plessy wanted to identify as white for the purpose of boarding the railroad car. ${ }^{106}$ His case, however, came to represent a claim for the dismantling of Jim Crow, especially when it was overturned in Brown v. Board of Education. ${ }^{107}$ In some sense, the transition from Plessy to Brown can be understood as a transition from seeking to "pass" as white to seeking to dismantle the racial hierarchy itself by eliminating de jure segregation. Sex discrimination doctrine needs to make the same kind of transformation. It is not enough for a transgender student to choose a particular sex-segregated restroom as an aspect of his or her gender identification. We should all be able to choose a restroom without engaging in gender identification.

\section{Public ReStRoOMS AS A CONSTITUTIONAL ViOLATION}

\section{A. State Action}

In order for a sex-based harm to be a constitutionally-based harm, there needs to be "state action" under the Fourteenth Amendment. ${ }^{108}$ Thus, one must initially ask the question whether sex-segregated bathrooms are the result of state action. The answer to that question is clearly, "yes." Indoor toilets at workplaces were not initially segregated by sex; Massachusetts became the first state in 1887 to require sex segregation of "water closets" at factories and

103 See generally Obergefell, 135 S. Ct. 2584.

104 Plessy v. Ferguson, 163 U.S. 537, 540 (1896), overruled by Brown v. Bd. of Educ., 347 U.S. 483 (1954).

105 Id. at 541-42; see also Cheryl I. Harris, Whiteness as Property, 106 HARV. L. REV. 1707, 1747 (1993) (discussing Plessy's claim for his property interest in his “whiteness”).

${ }^{106}$ Harris, supra note 105, at 1747.

107 Brown, 347 U.S. at 494-95.

108 U.S. ConST. amend. XIV, § 1 ("No State shall ... deny to any person within its jurisdiction the equal protection of the laws."). See generally Henry C. Strickland, The State Action Doctrine and the Rehnquist Court, 18 HASTINGS CONST. L.Q. 587 (1991) (discussing the historical development of this doctrine). 
other workplaces. ${ }^{109}$ Currently, most states require the sex segregation of public restrooms with "only a few exceptions for this rule, including private facilities and occupancies in which fifteen or fewer people are employed. ... The use of the public washroom of the 'wrong' sex might even lead to arrest." 110 Federal regulations require that places of employment offer sex-segregated restrooms. ${ }^{111}$ State law also requires sex-segregated restrooms at gas stations, mines, schools, restaurants, hotels, and swimming pools. ${ }^{112}$

\section{B. The Harm Created by Sex-Segregated Restrooms}

\section{Introduction}

Rather than argue that sex-segregated restrooms do not constitute sex discrimination, one could imagine a state actor arguing that it is a harmless example of sex discrimination, which need not invoke heightened scrutiny. As in Plessy v. Ferguson, the state could argue that the "enforced separation" of the two sexes does not stamp women with a "badge of inferiority."113 Paraphrasing the Plessy majority, as applied to the context of sex-segregated restrooms: "If this be so, it is not by reason of anything found in the [sex segregation], but solely because [women] choose[] to put that construction upon it." 114 The routine acceptance of sex-segregated public restrooms, however, does not dissipate the harms that result from this sex segregation. Those harms include both a violation of the principle of formal equality as well as an anti-stereotyping principle. ${ }^{115}$ As we will see below, both principles can exist simultaneously and together contribute to an understanding of sex discrimination, constitutional principles.

When Ruth Bader Ginsburg decided to bring some sex-equality cases that used men as plaintiffs in the 1970s, she was clearly marshaling principles of

109 Kogan, supra note 54, at 39.

${ }^{110}$ Braverman, supra note 78, at 58. For example, the New York State Plumbing Code provides: "Where plumbing fixtures are required, separate facilities shall be provided for each sex." Plumbing CODE OF N.Y. § 403.2 (2010).

${ }^{111}$ David S. Cohen, The Stubborn Persistence of Sex Segregation, 20 Colum. J. GENDER \& L. 51, 82 (2011).

112 Id.

113 See Plessy v. Ferguson, 163 U.S. 537, 551 (1896), overruled by Brown v. Bd. of Educ., 347 U.S. 483 (1954).

${ }^{114}$ See id.

115 See Cary Franklin, The Anti-Stereotyping Principle in Constitutional Sex Discrimination Law, 85 N.Y.U. L. REV. 83, 86 (2010) (arguing that Justice Ginsburg's work reflects a lifelong commitment to the anti-stereotyping principle); Reva B. Siegel, You've Come a Long Way, Baby: Rehnquist's New Approach to Pregnancy Discrimination in Hibbs, 58 STAN. L. REV. 1871, 1884 (2006) (arguing that Chief Justice Rehnquist's opinion in Nev. Dep't of Human Res. v. Hibbs, 538 U.S. 721 (2003), reflected an understanding of the importance of sex-role stereotyping as a key part of the Court's sex discrimination jurisprudence). 
formal equality to say that discrimination against men was as harmful as discrimination against women. ${ }^{116}$ In fact, that has become the "canonical account[]" of Ginsburg's litigation strategy. ${ }^{117}$ Nonetheless, rather than think of Reed v. Reed as merely a formal equality case, we should also think of that case as challenging the sex-role stereotype that assumed that a man should be the administrator of an estate. ${ }^{118}$ Similarly, Weinberger $v$. Wiesenfeld should be considered a case about a man who was the primary child caretaker and the wife who was the primary breadwinner. ${ }^{119}$ When Stephen Wiesenfeld's wife died giving birth to their first child, he was not able to attain Social Security benefits to stay home with the child. ${ }^{120}$ In ruling for Stephen Wiesenfeld, the Court held that Congress should not be permitted to enact legislation based on the assumption that mothers, but not fathers, should be able to stay out of the paid labor force after the birth of a child. ${ }^{121}$

The point in seeing the sex-stereotyping theory underlying much of the Court's constitutional, sex discrimination doctrine is that it allows us to better understand the kind of harm reflected in these cases. While it is true that some cases involved a loss of a certain tangible, financial benefit, such as Wiesenfeld's death benefit, others involved the noneconomic harm of being expected to conform to a gender-based norm. Sally Reed, who was a female plaintiff in one of the early sex-equality cases, wanted the opportunity to administer her son's estate after he committed suicide rather than have that role automatically go to her estranged husband. ${ }^{122}$ It is unlikely that the material benefits, if any, of administering the estate were a motivation for her in bringing the legal action.

Sex discrimination doctrine, itself, reflects the importance of both formal equality and an anti-sexual stereotyping theory when it articulates why heightened scrutiny is appropriate in this context. In Craig v. Boren, another case brought by a male plaintiff to advance formal equality, the Court explained that previous decisions relied on the determination that state statutes often fostered "“old notions' of role typing and preparing boys for their expected performance in the economic and political worlds." 123 It was the prevalence of those gender-based stereotypes in contemporary society that persuaded the Court in Craig to finally announce that it was using some form

\footnotetext{
116 See Franklin, supra note 115, at 87-88 (arguing that Justice Ginsburg "pressed the claims of male plaintiffs in order to promote a new theory of equal protection").

117 Id. at 86.

118 Reed v. Reed, 404 U.S. 71, 72-74 (1971).

119 Weinberger v. Wiesenfeld, 420 U.S. 636, 639-42 (1975).

${ }^{120}$ Franklin, supra note 115 , at 133 .

${ }^{121} I d$. at 136 (arguing that the government restricted "mother's benefits" to women "because it believed that they should not be required to work" (quoting Wiesenfeld, 420 U.S. at 650)).

122 Id. at 123 .

${ }^{123}$ Craig v. Boren, 429 U.S. 190, 198 (1976) (quoting Stanton v. Stanton, 421 U.S. 7, 14-15 (1975)).
} 
of heightened scrutiny in gender discrimination cases rather than mere rational basis scrutiny. 124 That articulation of heightened scrutiny, however, also clearly reflected strong principles of formal equality when the Court announced for the first time that "classifications by gender must serve important governmental objectives and must be substantially related to achievement of those objectives." 125 While the degree of scrutiny may have heightened over the years to an even stronger formal equality rule, ${ }^{126}$ the Court also continues to emphasize that the state's justifications "must not rely on overbroad generalizations about the different talents, capacities, or preferences of males and females."127 As Ruth Bader Ginsburg has moved from the lead lawyer in the early sex discrimination cases to the leading jurist in recent sex discrimination cases, the anti-stereotyping principle has become even more firmly embedded in constitutional doctrine as part of the core justification for a heightened scrutiny doctrine that reinforces formal equality.

\section{Sex-Segregated Bathrooms as Sexual Stereotyping}

Sexual stereotyping is at the core of the sex segregation of public restrooms. While state or commercial entities might justify the sex segregation of restrooms by noting the different ways that men and women urinate, those biological differences, in fact, have little to do with the sex segregation of restrooms. In the home, men and women are able to use the same restroom design. Outside the home, it might be convenient and efficient to offer urinals to men, and toilet stalls with small trash cans for men or women, but these design options have nothing to do with the need to sex segregate public restrooms. Urinals, like toilets, could have privacy barriers. Toilet stalls already have privacy barriers. While it may be true that men have been socialized to urinate standing up, that difference does not even require entirely different construction designs. ${ }^{128}$

The real explanation for sex segregation of restrooms flows from the racial, ethnic, class, and gender stereotypes underlying the rules and policies governing restrooms. As we saw in Part II.A, the development of sex-

${ }^{124} I d$. at 197.

125 Id.

${ }^{126}$ In United States v. Virginia, Justice Ginsburg's majority opinion stated: "Without equating gender classifications, for all purposes, to classifications based on race or national origin, the Court, in post-Reed decisions, has carefully inspected official action that closes a door or denies opportunity to women (or to men)." United States v. Virginia, 518 U.S. 515, 532 (1996) (footnote omitted).

127 Id. at 533 .

128 There are many devices that women could use to urinate standing up, but those devices have never become popular. See Case, supra note 37, at 216-17. In the military, women have experimented with a variety of approaches that allow them to use the toilet as efficiently as men, including the use of a spout tube. See Nancy Steele \& Linda H. Yoder, Military Women's Urinary Patterns, Practices, and Complications in Deployment Settings, 33 UROLOGIC NURSING 61, 66 (2013). 
segregated restrooms accompanied race and class segregation. The privacy justification is actually a pretext for the articulation of gender stereotypes about the inappropriateness of men being exposed to women's private, bodily functions. ${ }^{129}$ If all public restrooms had fully enclosed private stalls, akin to the current configuration of women's restrooms, many men would probably still be uncomfortable being in close proximity to a woman, especially as she might change a menstrual pad. Taboos against men being exposed to women's menstruation cycles are persistent and longstanding. ${ }^{130}$ In 2015, thenpresidential candidate Donald Trump seemingly alluded to a woman's menstrual cycle when he insulted Republican debate moderator Megyn Kelly by saying she had "[b]lood coming out of her wherever." 131 His comment reflected the continuing discomfort that men may feel in even thinking about women's private bodily processes. ${ }^{132}$ The history of public restroom construction suggests that men and women are not merely segregated to protect them from seeing each other's genitals. They are sex segregated to keep men and women protected from even hearing each other's "organic processes." 133

The construction of restrooms has been part of the broader "gender policing" that is fundamental to society. For white women, who have had access to sex-segregated restroom facilities since the late nineteenth century, these facilities can be seen as reflecting protection of the cult of true womanhood, ${ }^{134}$ with its heightened concern for women's privacy, frailty,

129 See supra Part II.A.

${ }^{130}$ See Irene Bruce, There Will (Not) Be Blood, GrinNell C.: Hist. MED. AM. (July 23, 2015), http://lewiscar.sites.grinnell.edu/HistoryofMedicine/uncategorized/there-willnot-be-blood/ [https://perma.cc/9WKU-3RTG].

${ }^{131}$ See Holly Yan, Donald Trump's 'Blood' Comment About Megyn Kelly Draws Outrage, CNN POL. (quoting Donald Trump), http://www.cnn.com/2015/08/08/politics/don ald-trump-cnn-megyn-kelly-comment/ [https://perma.cc/2P42-L2L7] (last updated Aug. 8, 2015)

132 After then-candidate Hillary Clinton took a somewhat long bathroom break at a presidential debate, the Washington Post reported that then-candidate Donald Trump, at a campaign rally, said: "“I know where she went - it's disgusting, I don't want to talk about it,' Trump said, screwing up his face, as the crowd laughed and cheered. 'No, it's too disgusting. Don't say it, it's disgusting." Jenna Johnson, Donald Trump Says Clinton's Bathroom Break During the Debate Is 'Too Disgusting' to Talk About, WASH. POST (Dec. 21, 2015), https://www.washingtonpost.com/news/post-politics/wp/2015/12/21/donaldtrump-calls-hillary-clinton-disgusting-for-using-the-restroom-during-a-debate/?utm_term=. $1 \mathrm{fc} 7 \mathrm{aa0d} 8507$ [https://perma.cc/67QB-V6KN]. Those comments suggest he found the thought of women's bodily functions as "disgusting" even when not tied to menstruation (since Clinton was obviously too old to be menstruating).

133 See Baldwin, supra note 2, at 267.

${ }^{134}$ See Barbara Welter, The Cult of True Womanhood: 1820 - 1860, 18 AM. Q. 151, 152 (1966) (discussing how women were judged on the basis of their "piety, purity, submissiveness and domesticity”). 
cleanliness, and need for moral protection. ${ }^{135}$ Women's restrooms have been historically constructed to provide more privacy from the entrance to the interior, as well as more privacy within the structure itself, than men's restrooms. Thus, it was considered inappropriate even to be able to see the "feet and lower parts of the skirts of females" when they were in the restroom. ${ }^{136}$ In fact, it was even considered inappropriate to be able to see a middle-class woman entering the restroom. ${ }^{137}$ The sex-segregated restroom was therefore part of the larger separate spheres discourse that was rampant in the nineteenth century.

The contemporary division of restrooms into "male" and "female" also reinforces gender policing by reinforcing the myth that all individuals readily fit into the male or female category. ${ }^{138}$ Both the transgender rights movement and the debate about intersex athletes challenge those rigid norms. Transgender high school students, like Gavin Grimm, have been forced to choose between the binary "male" and "female" restrooms as they outwardly transition their gender identity. ${ }^{139}$ Similarly, intersex athletes like Maria Patiño, who has XY chromosomes accompanied by androgen insensitivity which causes her to look conventionally female while having XY chromosomes, must face public debate about which of the two binary categories fits her. ${ }^{140}$

Before one enters a restroom, one often looks up and glances at a stick figure that depicts males and females in a stereotypical fashion. ${ }^{141}$ Even if the

${ }^{135}$ For an excellent discussion of the cult of true womanhood and how it legitimized the sexual abuse of African-American women, see Harris, supra note 67, at 341, examining how "[d]efining true womanhood along a line of racial caste had the effect of sharply delineating both race and gender on premises that enshrined racial patriarchy."

${ }^{136}$ Kogan, supra note 54, at 48 (quoting 1 REPORT ON CONDITION OF WOMAN AND Child WAGE-EARNERS IN THE United STATES IN 19 Volumes, S. Doc. No.61-645, at 371 (1910)).

${ }^{137} I d$. at $48-49$ ("[M]erely shielding a woman while she was in the process of using the water-closet was not enough. Victorian modesty was threatened if a woman could even be seen entering the facility.").

138 See generally Nancy Levit, Keeping Feminism in Its Place: Sex Segregation and the Domestication of Female Academics, 49 U. KAN. L. REV. 775 (2001) (discussing the unconscious bias that accompanies sex segregation).

${ }^{139}$ See G.G. ex rel. Grimm v. Gloucester Cty. Sch. Bd., 822 F.3d 709, 716 (4th Cir. 2016), vacated and remanded, No. 16-273, 2017 WL 855755 (S. Ct. Mar. 6, 2017) (mem.).

140 See More, supra note 38, at 299.

141 There is wide variation to these depictions. At ethnic restaurants, for example, it is common to have various outfits or costumes on the men or women to signify the gendered differentiation. The triangle dress is the most common, but not only, demarcation found in public restrooms to distinguish between the men's and women's facility. For variations on these pictograms, see Marissa, Go Where? Sex, Gender, and Toilets, Soc'y PAGES (Sept. 2, 2010), https://thesocietypages.org/socimages/2010/09/02/guest-post-go-where-sex-genderand-toilets/ [https://perma.cc/2D4J-528E]. For discussions on what future restroom pictograms could look like, see Kerry Lauerman \& Chris Barber, What Should Be the Restroom Sign of the Future?, WASH. POST (June 6, 2016), https://www.washingtonpost.co 
iconic stick figures are absent, our brains are required to engage in gender sorting before we enter the restroom. ${ }^{142}$ "Female" or "male," we think to ourselves as we enter the appropriate space each day. ${ }^{143}$ Thus, not surprisingly, parents who opposed Gavin Grimm using the male restroom argued that his action might signify that "non-transgender boys would come to school wearing dresses in order to gain access to the girls' restrooms." 144 Were they really concerned with boys seeking to use the girls' restrooms or were they actually concerned that boys might want to wear dresses? These parents implicitly understood that sex-segregated restrooms were a type of gender policing. They did not want the school district to relax its gender policing. The long-standing case law against sexual stereotyping under Title VII of the Civil Rights Act of 1964, as well as the anti-sexual stereotyping theory that underlies constitutional, sex discrimination doctrine, ${ }^{145}$ however, should preclude the state from engaging in this kind of pervasive, gender policing. ${ }^{146}$

Ironically, the recent spate of cases involving transgender students who want to use a particular single-sex restroom reinforces the connection between restrooms and gender socialization. For example, Gavin Grimm's doctor argued that the school district's insistence that Gavin use a single stall rather than the boys' restroom 'accentuat[ed] his 'otherness,' undermining his identity formation, and impeding his medically necessary social transition process." 147 As part of his gender transition, Gavin wanted to look up and see the male stick figure as he entered the restroom, because the use of the singlesex restroom was a part of his gender-identity formation. ${ }^{148}$ Similarly, the parents of some of the other male children were afraid that relaxing the norms for restroom access would cause their boys to abandon their mandated gender roles and start coming to school wearing dresses. ${ }^{149}$ Thus, even as some people might argue that sex segregation is utterly harmless, others are lined up

m/news/post-nation/wp/2016/06/06/what-should-be-the-restroom-sign-of-the-future/ [http s://perma.cc/288K-UAEW].

142 This kind of repeated, gender sorting could help lead to the concept of "implicit bias," which is increasingly acknowledged as a factor in the perpetuation of discrimination. See generally Anthony G. Greenwald \& Linda Hamilton Krieger, Implicit Bias: Scientific Foundations, 94 CALIF. L. REV. 945 (2006) (recognizing the importance of beliefs in shaping behaviors even if those beliefs are not consciously endorsed).

${ }^{143}$ Braverman, supra note 78, at 46 ("We visit washrooms several times a day. Based on an average of eight minutes a day, we will all spend roughly 3,650 hours or 150 days in the washroom in the course of our lives.").

144 Grimm, 822 F.3d at 716.

145 See supra Part III.B.1.

146 See generally Price Waterhouse v. Hopkins, 490 U.S. 228 (1989) (recognizing sexual stereotyping as a violation of Title VII).

${ }^{147}$ Grimm, 822 F.3d at 727-28 (Davis, J., concurring) (quoting Doctor Randi Ettner, a psychologist specializing in "working with children and adolescents with gender dysphoria").

${ }^{148}$ Id. at 716-17 (majority opinion).

${ }^{149}$ See id. at 716. 
arguing for stark sex segregation out of recognition of the role that sexsegregated restrooms play in the socialization of gender.

\section{Women's Exclusion from All-Male Space}

The harm from the sex segregation of bathrooms, however, is not limited to a stereotype harm. Genuine social and business harms flow from this sex segregation that can be understood as a more traditional violation of formal equality principles.

At a time when protective labor legislation was emerging, Massachusetts became the first state to require that workplace toilet facilities be sex segregated. ${ }^{150}$ While the historical roots of this sex-segregation legislation may have been "to protect the weaker body of the woman worker," 151 it has been maintained long after such views of women have been largely rebuffed. Sex-segregated restrooms endure as spaces where business and social interactions inevitably take place.

The existence of sex-segregated restroom space within the public sphere is nearly universally accepted. If job categories were sex segregated at a workplace, people would quickly complain. ${ }^{152}$ Given the number of times a day we might use a communal restroom at a workplace, educational entity, or public arena, it is hard to measure the lack of opportunity for cross-sex social or business interactions. Using the restroom is not merely about using the restroom; it is also about the conversations that may occur in that space. ${ }^{153}$ Within places of employment, for example, casual or even business-related conversations do take place in sex-segregated restroom spaces that help sustain the "old boys network." 154 For example, Professor Mary Anne Case recites a

${ }^{150}$ Act of Mar. 24, 1887, ch. 103, § 2, 1887 Mass. Acts 668, 669. For a discussion of the Massachusetts law, see Kogan, supra note 54, at 15 \& n.51, 39.

${ }^{151}$ Kogan, supra note 54 , at 41.

152 See, e.g., Babrocky v. Jewel Food Co., 773 F.2d 857, 859 (7th Cir. 1985) (successful challenge to sex-segregated job categories).

${ }^{153}$ In my attempt to ask men about how much conversation occurs in restrooms and my attempt to find articles on the subject, I have found a wide range of views. As the following reveals, however, it is clear that some men engage in business-related talk in a restroom. See Kittyprecious, Why Do Some Men Hang Out to Talk in Office Restrooms?, ASK METAFILTER (June 23, 2008, 8:06 AM), http://ask.metafilter.com/94772/Why-dosome-men-hang-out-to-talk-in-office-restrooms [https://perma.cc/P8ZF-ZKN7]. In my lifelong experience using women's restrooms, I can report that women often do chat in restrooms with a variety of conversational topics. Although an argument about the harm to men from being excluded from women's restrooms is not at the heart of my argument, I would acknowledge that men are arguably harmed by missing the common social interactions that occur among women in public restrooms.

${ }^{154}$ Although it is a mere anecdote, I still remember encouraging a female legal writing instructor to apply for a tenure-track position in a restroom at a university where I taught. When she achieved that higher rank, I often wondered what would have happened if we had not chatted in the restroom. 
story of a litigation partner at a firm who would say to his male colleagues, "Come pee with me." 155

Further, the male restroom has historically been a site of male political interactions. Then-presidential candidate John Kerry said that he was surprised at the "number of people who tried to introduce themselves to him in the men's room." 156 Thus, it should come as no surprise that the United States did not even have a women's restroom on the Senate floor until 1992;157 no one expected women to enter or mingle in that political space at all. Their exclusion from the restroom was symbolic of their exclusion from the political space itself.

Women's exclusion from all-male spaces may also cause women to have inadequate information to assess a man's suitability for political office. Women have a right to hear the lewd or demeaning comments that men might make in those spaces, as well as engage in more positive interactions with them. For example, the lewd and demeaning comments about women that then-presidential candidate Donald Trump made while in the all-male setting of a work-related bus ${ }^{158}$ may have heightened the gender gap in the presidential election when female voters gained access to that speech through an audio recording and were alarmed by its content. ${ }^{159}$ More typically, women have no opportunity to overhear such conversations.

Of course, it may also be possible that men might be less inclined to make lewd and demeaning comments about women if women were present in previously all-male spaces. ${ }^{160}$ There is a broad literature on how all-male

155 Case, supra note 37, at 224.

156 Id.

157 Braverman, supra note 78, at 60.

${ }^{158}$ See Fahrenthold, supra note 36. In the tape, Trump's conversation becomes polite and nonsexist as soon as he exits the bus and is in the company of a woman. See id. Trump generically described this all-male bus as a "locker room," although it was not a locker room. See Emily Crockett, Trump's Leaked Comments Aren't Just "Lewd." They Describe Sexual Assault., Vox (Oct. 7, 2016), http://www.vox.com/identities/2016/10/7/13206174/tr ump-leaked-lewd-pussy-comments-women-rape-sexual-assault [https://perma.cc/HY64$6 \mathrm{WKJ}]$. His reference to a locker room was likely his way of characterizing this space as a private, all-male space. He did not consider it appropriate for his fitness for political office to be judged, in part, by what he said in such an all-male space. See id.

${ }^{159}$ While Hillary Clinton reportedly received more votes from women than men (consistent with recent experiences by Democratic candidates), this gender gap was even larger than in recent elections. See Alec Tyson \& Shiva Maniam, Behind Trump's Victory: Divisions by Race, Gender, Education, PEW RES. CTR. (Nov. 9, 2016), http://www.pewresearch.org/fact-tank/2016/11/09/behind-trumps-victory-divisions-by-race -gender-education/ [https://perma.cc/4EZ2-8JQ4]. Thus, overall, gender played a larger predictive role than in previous presidential contests with men seemingly less concerned than women about Trump's sexist remarks. Further, men may have been less willing than women to vote for a female candidate for President.

${ }^{160}$ See, e.g., Carol Dyhouse, Troubled Identities: Gender and Status in the History of the Mixed College in English Universities Since 1945, 12 WOMEN's HIST. REV. 169, 179 (2003). 
colleges changed when they became coed, with some arguing that men's colleges became more civilized under coeducation, with fewer incidents of "gang hooliganism."161 Intermittent sex-integrated restroom access is obviously different than a university offering classes on a sex-integrated basis. Nonetheless, there is little doubt that women's presence in a social environment has an effect on speech and behavior. ${ }^{162}$ If a side effect of sexintegrated restroom space is that men lose one context in which to make lewd or demeaning comments about women, then such a change would have an additional positive effect on women's status in society.

\section{Some Doctrinal Complications}

The constitutional harm argument that has been presented above assumes that a court would agree that the sex segregation of public restrooms constitutes an act of sex discrimination itself. There is a line of case law, which has continued vitality, that suggests that governmentally-imposed sex discrimination, when justified by the biological differences between men and women, does not constitute sex discrimination for the purpose of constitutional law. Support for this argument can be found in Geduldig v. Aiello. ${ }^{163} \mathrm{In}$ an often repudiated footnote, ${ }^{164}$ the Court explained that it did not review the state's exclusion of normal pregnancy from its disability program under heightened scrutiny, because "[t]he California insurance program does not exclude anyone from benefit eligibility because of gender but merely removes one physical condition-pregnancy - from the list of compensable disabilities."165 Although Justice Ginsburg has argued that the Geduldig case is "senseless[],"166 and no longer reflects an appropriate way to think about sex discrimination, ${ }^{167}$ she has also maintained the "inherent differences" line of reasoning in her majority opinion in United States v. Virginia. In her opinion for the Court, she stated: “'Inherent differences' between men and women, we have come to appreciate, remain cause for celebration, but not for

${ }^{161} I d$. (quoting the warden of University House, Birmingham).

162 See, e.g., Peter Kollock et al., Sex and Power in Interaction: Conversational Privileges and Duties, 50 AM. Soc. REV. 34, 42-45 (1985); Lynn Smith-Lovin \& Charles Brody, Interruptions in Group Discussions: The Effects of Gender and Group Composition, 54 AM. SoC. REV. 424, 432-34 (1989).

163 Geduldig v. Aiello, 417 U.S. 484, 496 \& n.20 (1974).

164 See, e.g., Cornelia T.L. Pillard, Our Other Reproductive Choices: Equality in Sex Education, Contraceptive Access, and Work-Family Policy, 56 EMORY L.J. 941, 972 \& n.102 (2007) (arguing that Geduldig is wrong and that "scholarly consensus is strongly critical of Geduldig"); Siegel, supra note 115, at 1892 \& n.103 (arguing that the recent Nev. Dep't of Human Res. v. Hibbs, 538 U.S. 721 (2003), decision limited Geduldig's reach)

165 Geduldig, 417 U.S. at 496 n.20.

166 Coleman v. Court of Appeals of Md., 566 U.S. 30, 59 (2012) (Ginsburg, J. dissenting) (plurality opinion).

${ }^{167} I d$. at 59 n.6 (describing the holding in Geduldig as an "embarrass[ment]"). 
denigration of the members of either sex or for artificial constraints on an individual's opportunity."168

Justice Ginsburg's recitation of the inherent differences rule admittedly creates continued ambiguity in sex discrimination doctrine. Did she mean (as in Geduldig) that the acceptance of an inherent differences argument requires that the level of scrutiny should be reduced to mere rational basis scrutiny? ${ }^{169}$ Or did she mean that a court could consider the articulation of an inherent differences argument as a justification for state-mandated sex discrimination after the plaintiff established a constitutional harm? Given her prior repudiation of Geduldig, the former interpretation seems unlikely. The latter interpretation would push this biological argument to the justification stage but not lower the level of scrutiny.

Even if it were true that different treatment based on inherent differences does not constitute sex discrimination and therefore lowers the level of scrutiny (as in Geduldig), it is hard to see how that rule is relevant to the sexsegregated bathroom context. Although men and women do have some differences in how they urinate, those differences do not necessitate differences in the construction of toilets. ${ }^{170}$ Men and women may prefer different toilet styles for urinating, but a restroom need not be sex segregated in order to accommodate more than one toilet design (as restrooms typically offer one handicap-accessible toilet within a standard restroom). Thus, the sex segregation of restrooms does not inevitably result from the typical biological differences between how men and women urinate. We could have many different toilet designs within a single restroom. ${ }^{171}$

The rationales for sex segregation in bathrooms are privacy and safety, not biology. In United States v. Virginia, the State tried to assert the inherent biological differences argument, but the Court rejected that argument as a mere pretext for discrimination. ${ }^{172}$ One would therefore expect the Court to reject the assertion of biological differences as an excuse to avoid the heightened scrutiny framework and, instead, require the state to justify that it has sufficiently strong reasons to maintain sex-segregated facilities. We need to examine whether those justifications should pass muster under the Court's constitutional sex discrimination doctrine.

168 United States v. Virginia, 518 U.S. 515, 533 (1996).

169 See Geduldig, 417 U.S. at 494-96, 496 n.20.

${ }^{170}$ See generally Anthony \& Dufresne, supra note 14 (discussing a variety of toilet designs that could equally accommodate men and women).

171 That solution would also facilitate the principle of universal design, which is favored in the disability context. See, e.g., Douglas K. Rush \& Suzanne J. Schmitz, Universal Instructional Design: Engaging the Whole Class, 19 WIDENER L.J. 183, 186 (2009).

${ }^{172}$ United States v. Virginia, 518 U.S. at 533-34. 


\section{Justifications for Sex Segregation}

The common explanations for sex-segregated bathrooms are privacy and safety. Thus, when Gavin Grimm sought to use the male restroom, parents complained "that permitting G.G. to use the boys' restroom would violate the privacy of other students and would lead to sexual assault in restrooms."173 Those arguments, however, are based on gendered and heteronormative assumptions, which are similar to the discredited arguments used to ban openly gay men and lesbians from positions in the military, ${ }^{174}$ and should no longer be acceptable.

\section{Privacy}

The Court's current jurisprudence can lend some support to a state's privacy argument that it is entitled to sex-segregated restrooms, but closer examination of those claims reveal they are vulnerable to challenge.

The Commonwealth of Virginia raised the privacy argument in United States $v$. Virginia. It argued that privacy was nearly nonexistent in the spartan barracks. ${ }^{175}$ The district court used the privacy rationale to rule in favor of the State, finding that co-education would require "[a]llowance for personal privacy." 176 The Fourth Circuit reversed the district court's conclusion that the State had not violated the Constitution but remanded for consideration on three issues, including the question of whether "the absence of privacy" would be "materially affected by coeducation." 177 On remand, the State argued, and the court of appeals agreed, while "applying a heightened intermediate scrutiny test," 178 that the State was entitled to meet its interests by continuing to exclude women from Virginia Military Institute (VMI) and create a parallel program for women at another university. ${ }^{179}$ The privacy rationale was an accepted justification for state-imposed sex segregation under the heightened scrutiny framework.

The Supreme Court reversed the court of appeals in United States $v$. Virginia but did not address the privacy rationale that was accepted by the lower courts. ${ }^{180}$ Instead, it focused on whether the female-only program that

173 See G.G. ex rel. Grimm v. Gloucester Cty. Sch. Bd., 822 F.3d 709, 716 (4th Cir. 2016), vacated and remanded, No. 16-273, 2017 WL 855755 (S. Ct. Mar. 6, 2017) (mem.).

${ }^{174}$ See Gregory M. Herek \& Aaron Belkin, Sexual Orientation and Military Service: Prospects for Organizational and Individual Change in the United States, in 4 MILITARY LifE: The Psychology of SERVING IN PEACE AND Combat 119, 128-29 (Thomas W. Britt et al. eds., 2006).

175 United States v. Virginia, 518 U.S. at 522.

176 United States v. Virginia, 766 F. Supp. 1407, 1412 (W.D. Va. 1991).

${ }^{177}$ United States v. Virginia, 976 F.2d 890, 896-97, 899-900 (4th Cir. 1992).

178 United States v. Virginia, 44 F.3d 1229, 1232 (4th Cir. 1995).

${ }^{179}$ Id. at $1237-41$.

${ }^{180}$ United States v. Virginia, 518 U.S. at 553-54. 
the State proposed creating was genuinely equal to the one at VMI. ${ }^{181}$ Although the majority's opinion in United States $v$. Virginia did not directly require the State to allow women to enroll at VMI, its blistering criticism of the tangible and intangible harm that resulted from women's exclusion suggests that sex integration was the only available remedy. ${ }^{182}$ Nonetheless, the Supreme Court was aware that the all-male facility at VMI had a militarystyle residence ${ }^{183}$ where, presumably, the students would have a lack of privacy.

The majority's holding in United States $v$. Virginia says little about how it resolved the State's privacy argument except for a brief comment in a footnote that "[a]dmitting women to VMI would undoubtedly require alterations necessary to afford members of each sex privacy from the other sex in living arrangements." 184 Was the privacy argument outweighed by the harm to women? Or was there no genuine state interest in such privacy arguments, once minor adjustments were made? Chief Justice Rehnquist's separate concurrence argued that the State should have been able to devise another sexsegregated program because VMI showed the coed program would have to be "fundamentally altered if it admitted women," in part, because there would have to be "new allowances for personal privacy." 185 Because the majority did not accept Rehnquist's views, we must presume the majority disagreed with them. The majority's refusal to embrace Rehnquist's solution suggests that it thought women could not be excluded from VMI merely on the basis of a privacy rationale. Nonetheless, the majority opinion does not provide direct guidance on the privacy issue; this analysis is by implication.

Similarly, the Fourth Circuit's recent decision in favor of Gavin Grimm does not give us much insight into how it considered the school district's privacy argument. The Fourth Circuit acknowledged the privacy interest in sex-segregated restrooms:

We agree that it has indeed been commonplace and widely accepted to separate public restrooms, locker rooms, and shower facilities on the basis of sex. We agree that 'an individual has a legitimate and important interest in

${ }^{181}$ Id

182 See id. Thus, Chief Justice Rehnquist concurred separately to argue that "the remedy should not necessarily require either the admission of women to VMI or the creation of a VMI clone for women." Id. at 565 (Rehnquist, C.J., concurring in judgment).

${ }^{183}$ Id. at 548 (majority opinion) ("VWIL students thus do not experience the "barracks' life "crucial to the VMI experience ...."” (quoting United States v. Virginia, 766 F. Supp. 1407, 1423 (W.D. Va. 1991))).

${ }^{184}$ Id. at 550 n. 19 .

${ }^{185} \mathrm{Id}$. at 588 (Scalia, J., dissenting). 
bodily privacy such that his or her nude or partially nude body, genitalia, and other private parts' are not involuntarily exposed. ${ }^{186}$

But the Fourth Circuit found that this case was merely an administrative law case, which did not raise constitutional privacy issues, ${ }^{187}$ so these concerns did not need to be considered in the context of the case. ${ }^{188}$

The Grimm district court, however, gave significant consideration to the privacy justification for sex segregation. Citing cases involving prisoners, it noted that individuals "have a special sense of privacy in their own genitals." 189 While recognizing that the school district had modified the boys' restrooms to alleviate this privacy concern, the district court found "no amount of improvements to the urinals can make them completely private because people sometimes turn while closing their pants." 190 The district court failed to explain why it is permissible to put boys in a situation where other boys might see their genitals but not permissible to put boys in a situation where a transgender boy (or even a girl) might see their genitals. The evocation of "privacy," as articulated by the district court, has an implicit gendered assumption - that it is acceptable for restrooms to traditionally offer girls and women complete shielding from others seeing their "private parts" while not offering boys and men the same degree of privacy. If it is problematic for boys to have to expose their genitals to others in order to urinate, then one might argue that all boys have a privacy interest in the reconfiguration of their restrooms. Neither the district court nor the Fourth Circuit explained why girls but not boys should have an expectation of privacy when using the restroom.

To understand the privacy argument in the sex-segregated restroom context, it is helpful to remember the original description of the changes that were predicted to result after ratification of the ERA. Proponents of the ERA contended that restrooms could still be sex segregated after the ERA was ratified because "under current mores, disrobing in front of the other sex is

186 G.G. ex rel. Grimm v. Gloucester Cty. Sch. Bd., 822 F.3d 709, 723 (4th Cir. 2016) (agreeing with $i d$. at 734 (Niemeyer, J., concurring in part and dissenting in part)), vacated and remanded, No. 16-273, 2017 WL 855755 (S. Ct. Mar. 6, 2017) (mem.).

${ }^{187}$ The original claim for relief, however, did make a Fourteenth Amendment claim that was not even discussed by the district court. See G.G. ex rel. Grimm v. Gloucester Cty. Sch. Bd., 132 F. Supp. 3d 736, 738 (E.D. Va. 2015), rev'd in part and vacated in part, 822 F.3d 709 (4th Cir. 2016), vacated and remanded, No. 16-273, 2017 WL 855755 (S. Ct. Mar. 6, 2017) (mem.); Complaint III 53-60, Grimm, 132 F. Supp. 3d 736 (No. 4:15cv54), 2015 WL 4086446.

188 Grimm, 822 F.3d at 723-24.

189 Grimm, 132 F. Supp. 3d at 751 (quoting Lee v. Downs, 641 F.2d 1117, 1119 (4th Cir. 1981)).

${ }^{190}$ Id. When men have read this draft, they have often commented that it would be extremely uncommon for a boy or man in a public restroom to "turn while closing their pants." If that observation is accurate, it is interesting to note that the district court judge invented or exaggerated a privacy issue in order to justify the sex segregation of restrooms. 
usually associated with sexual relationships."191 In other words, ERA proponents considered the desegregation of restrooms (along with women in the military and same-sex marriage) to be too controversial to pursue when the ERA was first proposed. This view was based on sexist and heteronormative assumptions, as revealed in the above quote which explicitly references "[hetero]sexual relationships." 192 While women should not possibly be exposed to male genitalia in a restroom, it is acceptable for men to be exposed to the genitalia of other men in a public restroom. Boys and men are expected to publicly display their penises while also following "masculine homophobic imperatives that exclude homosexual contact." 193 Men are expected to have a lesser sense of privacy than women; women cannot even use the legal system to acquire men's lesser version of privacy. ${ }^{194}$ This gendered and heteronormative notion of privacy should be considered antiquated in light of the advancements in LGBT rights. Men and women, gay and straight people, should have equal claims to a right to privacy. The current configuration of bathrooms privileges heterosexual women's privacy concerns while also promoting the stereotype that women are the weaker sex needing protection.

Further evidence of the pretextual nature of the privacy argument is that public restrooms are typically sex segregated even when they contain only one stall. People enter these restrooms one at a time; they are not a shared space where men or women might see each other's private body parts. One can only imagine that the reason for that commonplace practice is the social discomfort in a woman entering a space that was previously occupied by a man or vice versa. But those feelings have no basis in anything but sexual stereotyping; they cannot be based on a genuine interest in privacy because those single stalls are entirely private.

\section{Safety}

Safety concerns are also used to justify sex-segregated bathrooms and to limit those facilities to individuals who were born to a particular sex or had surgery to transition them to a particular sex. Thus, the Ninth Circuit accepted a safety argument in finding no Title VII liability for a community college that precluded a woman from using the female restroom until she had completed sex reassignment surgery. ${ }^{195}$ In Grimm, the school district also offered a safety

191 Brown et al., supra note 89 , at 901 .

192 Id.

193 Ara Wilson, The Infrastructure of Intimacy, 41 SigNs 247, 255 (2016).

${ }^{194}$ For a provocative discussion of a case in which a female lineman unsuccessfully complained that she was a victim of a hostile work environment because all the employees (who were men) were expected to urinate outside (rather than in a restroom), see Mary Anne Case, All the World's the Men's Room, 74 U. CHI. L. REV. 1655, 1667 (2007) ("[M]en get what they are seen to want ....").

195 See Kastl v. Maricopa Cty. Cmty. Coll. Dist., 325 F. App’x 492, 493-94 (9th Cir. 2009). 
concern to justify keeping the transgender, male plaintiff out of the boys' restroom. ${ }^{196}$ Like the privacy argument, this argument is also based on gendered and heteronormative assumptions.

These kinds of safety concerns were previously recognized to keep women out of male, high-security prisons. In a famous sentence, Justice Stewart, writing for a majority of the Supreme Court in 1977, stated: "The employee's very womanhood would thus directly undermine her capacity to provide the security that is the essence of a correctional counselor's responsibility."197 Such concerns are no longer accepted to keep women out of jobs as guards in male prisons. ${ }^{198}$

Sex segregation can create, rather than solve, safety concerns. For example, sex-based segregation sometimes causes parents to allow their young children to enter a restroom by themselves when they are really too young to do so safely. In 1998, an aunt was horrified to discover that a man murdered her nephew in the men's room while the aunt dutifully waited outside for her nephew to use the facility by himself. ${ }^{199}$ People with disabilities who might benefit from assistance from an opposite-sex companion sometimes find themselves using a facility alone at some danger to their personal safety. ${ }^{200}$

The genuine safety concern stems from the fact that women and girls are disproportionately victims of sexual violence by men. ${ }^{201}$ Men already sexually assault some girls and women by lying in wait for them outside women's restrooms. Having men able to enter these restrooms freely, where girls and women may be present, could arguably increase their risk of sexual assault on the assumption that other men and women, if present in the restroom, would not be able to or willing to render any assistance. ${ }^{202}$

This safety argument seems to presume, inappropriately, that men typically lay in wait outside the women's restroom rather than enter to engage in a sexual assault. It is hard to understand how keeping all men outside of the restroom used by a woman makes the space safer when the man who is interested in committing an unlawful sexual assault is probably not especially concerned about the "women's" sign on the front entrance. Sheila Jeffreys has documented the various ways that women are already harassed by men in women's restrooms, including a practice called "upskirting," which involves

196 See G.G. ex rel. Grimm v. Gloucester Cty. Sch. Bd., 132 F. Supp. 3d 736, 750 (E.D. Va. 2015), rev'd in part and vacated in part, 822 F.3d 709 (4th Cir. 2016), vacated and remanded, No. 16-273, 2017 WL 855755 (S. Ct. Mar. 6, 2017) (mem.).

197 Dothard v. Rawlinson, 433 U.S. 321, 336 (1977).

198 Today, the cases are more likely to involve prisoners, rather than prison officials, objecting to the presence of female guards. See, e.g., Timm v. Gunter, 917 F.2d 1093, 1096 (8th Cir. 1990) (allowing female prison guards to engage in pat down searches of male inmates).

199 Anthony \& Dufresne, supra note 14, at 277.

200 See Schwarz, supra note 13, at 67-68.

201 See Jeffreys, supra note 51, at 47-48.

202 Id. at 48. 
"photographing up women's skirts without their knowledge."203 In support of her argument in favor of sex segregation, Jeffreys offers two anecdotes involving transgender women who had male genitalia and were able to use women's changing facilities. ${ }^{204}$ One of them reportedly displayed an erection in front of a woman within the changing room. ${ }^{205}$ These anecdotes, however, reflect changing rooms where there was no privacy from exposure of genitalia. If privacy safeguards are in place in restrooms, none of the opponents of the elimination of sex segregation have been able to offer concrete evidence of an increased risk of harm to women or men from the elimination of sex segregation. ${ }^{206}$

In considering the safety issue, it is also important to remember that sexual assault is not limited to men victimizing women. Men can sexually assault men; women can sexually assault women. Just as conventional notions of privacy offer more privacy to women than men, our desire to protect people from sexual assault when using the restroom may offer more protection to women than men. The aunt whose nephew was murdered in the men's restroom might feel that her nephew would have been much safer in the women's restroom, even if he had entered it alone. Mere assertions of safety without empirical evidence in support of those arguments cannot meet the required constitutional standard. It is possible that men might be less likely to assault women in a restroom if they thought another man might enter that space. Because of our historical practice of sex segregation, we have little basis to answer that question.

Due to the longstanding and unwarranted concerns about women's frailty, public entities should have to meet an objective legal standard before insisting on sex-segregated restrooms to further public safety. In the disability context, people have often been subject to similar stereotypes about safety issues, and the Department of Justice has created the following regulation to dictate how public entities can consider safety arguments in the disability context:

In determining whether an individual poses a direct threat to the health or safety of others, a public entity must make an individualized assessment, based on reasonable judgment that relies on current medical knowledge or on the best available objective evidence, to ascertain: the nature, duration, and severity of the risk; the probability that the potential injury will actually occur; and whether reasonable modifications of policies, practices, or

203 Id. at $48-49$.

204 Id. at 49.

205 Id.

${ }^{206}$ In the Grimm case, although the school district offered a safety rationale for excluding the plaintiff from using the boys' restroom, it offered no support for that argument. It merely said, "Parents have an interest in the safety of their children," without explaining how their policy enhances safety. Brief in Opposition to Motion for Preliminary Injunction at 11, G.G. ex rel. Grimm v. Gloucester Cty. Sch. Bd., 132 F. Supp. 3d 736 (E.D. Va. 2015) (No. 4:15-cv-00054-RGD-TEM), 2015 WL 11197852. 
procedures or the provision of auxiliary aids or services will mitigate the risk. ${ }^{207}$

This regulation would not work perfectly in the sex-segregated restroom context but could be modified to provide a parallel set of safety rules. One could say, for example:

In determining whether sex-integrated restrooms pose a direct threat to the health or safety of women or men, a public entity must make an assessment, based on reasonable judgment that relies on the best available objective evidence, to ascertain: the severity of the risk, the probability that the potential injury will occur, and whether reasonable modifications of restroom design will mitigate the risk.

Such a rule would be a big improvement over sex segregating public restrooms out of a purported safety concern merely because it has always been done that way. With such a safety rule in place, government entities would have to have some empirical basis in support of sex segregation; they could not impose it simply because it has always been that way.

Let me be clear: the safety of women and men, as well as boys and girls, while they use a public restroom is very important. Assuming that sex segregation solves the safety problem, without a close examination of the genuine ways in which sexual assault may occur in such spaces, advances sexual stereotypes while not necessarily advancing safety.

\section{FLIP THE DEFAULT RULES}

At the present time, various federal and state policies mandate sexsegregated restrooms for large communal facilities while also permitting various family-style or single-stall restrooms for those people who choose to use alternative facilities. The default policy is sex-segregated restrooms. The exception is restrooms open to people of any sex.

My suggestion is quite simple-we should flip the default rule. Public, communal restrooms should not be limited by sex. Within these restrooms, entities can provide a range of toilet styles with appropriate privacy barriers between stalls, as well as disability accessibility. ${ }^{208}$ Currently, restrooms have several configurations to provide accessibility to people who use wheelchairs

20728 C.F.R. § 35.139(b) (2016).

208 In the disability context, we emphasize principles of universal design so that individuals with disabilities do not need to seek accommodations or modifications of standard rules in order to gain access. See, e.g., Rush \& Schmitz, supra note 171, at 186. At present, people with disabilities who receive assistance from opposite-sex companions need to seek modification of sex-segregation rules in order to use communal restrooms. This Article's suggestion would eliminate the need for that request and therefore help people with disabilities appear less "exceptional" with respect to issues of gender and sexuality. 
or canes. It is possible to have more than one toilet configuration within a restroom. The default rule should therefore be sex-integrated toileting facilities. If entities choose to also provide a limited number of single-stall restrooms for people who might prefer not to use the large, communal restroom, then they can do so. Those single-stall restrooms should be available to a wide range of people and therefore include fully accessible toilets. ${ }^{209}$

One argument against the creation of sex-integrated restrooms is that it is unrealistic. Institutions won't build them, or people won't use them. Writing in 2007, Anthony and Dufresne documented that what they call "mixed-gender restrooms" do exist and are accepted at various locations. ${ }^{210}$ Ohio University, the University of New Hampshire, and other universities have been using such bathrooms for years. ${ }^{211}$ Ironically, the argument that "women won't use them" was the argument at the beginning of the twentieth century to justify having few public restrooms available for women. ${ }^{212}$ Today, it is more common for women to complain about a lack of available restrooms or longer lines at women's restrooms. So, we have flipped the default rule there; women have come to expect to find available restrooms in public spaces.

I can still remember the "bathroom" vote when I was living at the coed Radcliffe dorms while a student at Harvard University in the 1970s. As a sophomore in 1975 living in campus housing, we were told by our resident advisor that each hall would have a bathroom vote. If everyone voted to make the bathrooms coed then we could use any bathroom on the floor. If not, then the bathrooms on the floor would be designated male or female. We voted unanimously to make our bathrooms coed and became accustomed to seeing men and women enter and exit the restroom to use the shower or toilet. But I also remember my father coming to visit. He asked me, "Where is the men's room?" Unabashedly, I explained he could use any restroom. He responded, "I'll wait until we get to the restaurant." For me, the default rule had flipped so I was accustomed to using a coed restroom. For him, the default rule was

209 As a remedial matter, one would have to contend with what kind of "grandfather" rules to put in place. The ADA could serve as a useful guide. It requires entities to make existing facilities accessible where accessibility is "readily achievable" but new construction must be accessible. See, e.g., 28 C.F.R. $§ 36.304$ ("readily achievable" rule for existing facilities); 28 C.F.R. $\$ 36.401$ (new construction rule). One could imagine that facilities could be easily modified to comfortably accommodate both men and women (since houses usually have bathrooms that are used by both men and women). Architects with expertise in bathrooms are probably the appropriate professionals to make those recommendations and this Article does not claim to resolve those highly specific factual questions. For an example of such a restroom design, see JoAnn Hindmarsh Wilcox \& Kurt Haapala, How to Design School Restrooms for Increased Comfort, Safety and GenderInclusivity, ARCH DAILY (Nov. 15, 2016), http://www.archdaily.com/799401/how-todesign-school-restrooms-for-increased-comfort-safety-and-gender-inclusivity?utm_mediu $\mathrm{m}=$ email\&utm_source=ArchDaily\%20List [https://perma.cc/8N3F-3EER].

210 Anthony \& Dufresne, supra note 14 , at 282-83.

211 Id.

212 See Baldwin, supra note 2, at 266. 
firmly in place so he experienced discomfort until he could find a restaurant with a sex-segregated restroom.

It is time to flip the default rule by invalidating all the state and federal laws and policies that mandate sex-segregated restroom facilities. We'll get used to it. 